\title{
Correction: Osteoblastic heparan sulfate glycosaminoglycans control bone remodeling by regulating Wnt signaling and the crosstalk between bone surface and marrow cells
}

Rafik Mansouri ${ }^{1,2}$, Yohann Jouan ${ }^{1,2}$, Eric Hay ${ }^{1,2}$, Claudine Blin-Wakkach ${ }^{3,4}$, Monique Frain ${ }^{5}$, Agnès Ostertag ${ }^{1,2}$, Carole Le Henaff ${ }^{1}$, Caroline Marty ${ }^{1,2}$, Valérie Geoffroy ${ }^{1,2}$, Pierre J Marie ${ }^{1,2}$, Martine Cohen-Solal ${ }^{1,2}$ and Dominique Modrowski ${ }^{1,2}$

Correction to: Cell Death \& Disease; https://doi.org/ 10.1038/cddis.2017.287; published online 29 June 2017.
The PDF and HTML versions of the article have been updated to include the Creative Commons Attribution 4.0 International License information.

Published online: 16 July 2018

\footnotetext{
Correspondence: Dominique Modrowski (dominique.modrowski@inserm.fr) ${ }^{1}$ Inserm UMR-1132, BIOSCAR, Paris, France

${ }^{2}$ Université Paris Diderot, Sorbonne Paris Cité, Paris, France

${ }^{3}$ CNRS, UMR 7370, LP2M, Faculté de médecine, 28 avenue de Valombrose,

Nice, France

${ }^{4}$ Université Nice Sophia Antipolis, Parc Valrose, Nice, France

${ }^{5}$ CNRS, USR3695, Gif-sur-Yvette, France
}

(c) Open Access This article is licensed under a Creative Commons Attribution 4.0 International License, which permits use, sharing, adaptation, distribution and reproduction in any medium or format, as long as you give appropriate credit to the original author(s) and the source, provide a link to the Creative Commons license, and indicate changes were made. The images or other third party material in this article are included in the article's Creative Commons license, unless indicated otherwise in a credit line to the material. If material is not included in the article's Creative Commons license and your intended use is not permitted by statutory regulation or exceeds the permitted use, you will need to obtain permission directly from the copyright holder. To view a copy of this license, visit http://creativecommons.org/licenses/by/4.0/. 